\section{Performance of Sweetpotato Varieties Grown Using Black Plastic Mulch in Pennsylvania}

\author{
Luis O. Duque ${ }^{1}$
}

AdDitional INDEX wORDs. orange flesh, storage roots, U.S. No. 1, yield

Summary. Sweetpotato (Ipomoea batatas) production in Pennsylvania and the northeastern United States has been increasing steadily. The performance of eight commercially available sweetpotato varieties and two unreleased accessions grown on raised beds and covered with black plastic mulch in Pennsylvania was evaluated. All varieties and accessions were evaluated in 2 successive years (2018 and 2019) at Rock Springs, PA. There were statistically significant differences in total marketable yield (TMY), but not in all yield components in both years. 'Orleans', 'Beauregard', 'Averre', and 'Covington' consistently produced high marketable yields and suitable U.S No.1 grade storage roots. 'Bonita' (tan skin/white flesh) and 'Carolina Ruby' [red skin/orange flesh (OF)] produced consistent yields in both years (range, 330-430 bushels/acre; 50-1b bushel). NC413 [purple skin (PS)/purple flesh (PF)] produced the lowest yield in 2018 and was discarded for future trials. In 2019, NCP13-0030 (PS/PF) produced good yields and shapes comparable to OF varieties. Overall total yields (TYs) measured in this study compared satisfactorily with average nationwide yields, with several varieties producing more than $\mathbf{5 0 0}$ bushels/ acre.

$\mathrm{T}$ raditionally, commercial production of sweetpotatoes (Ipomoea batatas) has concentrated in the warmer states of the United States, with North Carolina, California, Arkansas, Florida, Louisiana, and Mississippi demonstrating more than $94 \%$ of total area planted for 2018 [U.S. Department of Agriculture (USDA), National Agricultural Statistics Service (NASS), 2020]. In stark contrast, the northeastern United States [defined here as the conjunct of states conforming the subregions of New England and the

Received for publication 14 July 2020. Accepted for publication 9 Sept. 2020.

Published online 6 October 2020.

${ }^{1}$ The Pennsylvania State University, Department of Plant Science, 109 Tyson Building, University Park, PA 16802

This work was supported by the Pennsylvania Department of Agriculture Specialty Crop Block Grant Program under Grant Agreement \#4417652 and the U.S. Department of Agriculture, National Institute of Food and Agriculture and Hatch Appropriations under Project \#PEN04582 and Accession \#1005492.

I thank the Russell E. Larson Agricultural Research Center farm staff and student interns at The Pennsylvania State University for technical assistance and support. I am also thankful to K.V. Pecota for providing thoughtful advice during the duration of this project. I also appreciate all the advice and collaboration of the National Sweetpotato Collaborator's Group.

L.O.D. is the corresponding author. E-mail: loduque@psu.edu.

This is an open access article distributed under the CC BY-NC-ND license (https://creativecommons.org/ licenses/by-nc-nd $/ 4.0 /$ ).

https://doi.org/10.21273/HORTTECH04689-20
mid-Atlantic (in all, Connecticut, Delaware, Maine, Maryland, Massachusetts, New Hampshire, New Jersey, New York, Pennsylvania, Rhode Island, and Vermont)] accounts for only $\approx 1300$ acres $(1.2 \%$ of the total U.S. acreage) harvested for fresh-market sweetpotatoes in 2017 (USDA, NASS, 2019). For that reason, the majority of sweetpotatoes consumed in the northeastern United States are shipped and distributed from southern U.S. states such as North Carolina and Louisiana.

Yet, sweetpotato is considered a resilient crop, well adapted to lowand high-input systems, and numerous types of soils and climates (Jansson and Raman, 1991), with their North American distribution ranging from Florida to southern Ontario, Canada (Bouwkamp, 1985). Progressively, more and more sweetpotato production research studies under shorter growing seasons and milder temperatures have been published
(Sideman, 2015; Wees et al., 2015, 2016).

Pennsylvania's sweetpotato acreage has grown slowly but steadily and now accounts for more than $4 \%$ of the total acreage harvested in the northeastern United States (USDA, NASS, 2019). The majority of Pennsylvania farmers plant and harvest sweetpotatoes as part of a diversified farmstead, with sweetpotato acreage fluctuating between 1 and 2 acres. Typically, farmers outsource second generation (G2) sweetpotato slips from certified producers in southern U.S. states, opting to purchase vigorous diseaseand virus-free slips as opposed to producing slips themselves.

Still, the greatest challenges for sweetpotato production in the northeastern United States including Pennsylvania are 1) a short growing season, 2) cool temperatures, 3) erratic and unpredictable rainfall patterns, and 4) nonadapted varieties, among many others. Northern and central Pennsylvania growers cannot plant in early spring because of cold soil temperatures, and must harvest early in the fall season before the first frost, resulting in a shorter growing season. One strategy is the use of raised beds coupled with black biodegradable or standard black plastic mulch films to increase early-season soil temperature and control for weeds (Hayes et al., 2019). However, there are increased labor, machinery, and supply costs associated with initial placement and subsequent removal and disposal of plastic after final harvest. This strategy has been examined extensively and was found to increase vegetable yields (Hayes et al., 2019). Another important factor for sweetpotato production is the use of adapted sweetpotato varieties that could yield well under northeastern U.S. conditions, as well as present suitable shapes and quality characteristics for local fresh markets.

\begin{tabular}{llll}
\hline $\begin{array}{l}\text { Units } \\
\begin{array}{l}\text { To convert U.S. to SI, } \\
\text { multiply by }\end{array}\end{array}$ & U.S. unit & SI unit & $\begin{array}{l}\text { To convert SI to U.S., } \\
\text { multiply by }\end{array}$ \\
\hline 0.4047 & $\mathrm{acre}(\mathrm{s})$ & $\mathrm{ha}$ & 2.4711 \\
0.3048 & $\mathrm{ft}$ & $\mathrm{m}$ & 3.2808 \\
2.54 & inch $(\mathrm{es})$ & $\mathrm{cm}$ & 0.3937 \\
0.4536 & $\mathrm{lb}$ & $\mathrm{kg}$ & 2.2046 \\
1.1209 & $\mathrm{lb} / \mathrm{acre}$ & $\mathrm{kg} \cdot \mathrm{ha}^{-1}$ & 0.8922 \\
0.0254 & $\mathrm{mil}(\mathrm{s})$ & $\mathrm{mm}$ & 39.3701 \\
$\left({ }^{\circ} \mathrm{F}-32\right) \div 1.8$ & ${ }^{\circ} \mathrm{F}$ & ${ }^{\circ} \mathrm{C}$ & $\left({ }^{\circ} \mathrm{C} \times 1.8\right)+32$
\end{tabular}


Numerous studies have shown the positive impact of plastic mulch on the growth of sweetpotato both in the United States and Canada. In New Hampshire, Sideman (2015) examined sweetpotato growth using both biodegradable and nondegradable black plastic mulch, with variable results depending on varieties tested. In Iowa, Nair et al. (2012) tested different colored plastic mulches using 'Beauregard' and 'Evangeline'. Their results demonstrated no statistically significant differences between the different color mulches tested with regard to final yield. In New York, Bornt (2012) used traditional black plastic mulch and infrared transmitting mulch with no statistically significant differences in yield among the sweetpotato varieties examined. In Canada, Wees et al. $(2015,2016)$ examined more than 15 sweetpotato varieties under biodegradable and nondegradable black plastic mulch and different planting densities. Their results were variable under these conditions, but suggested that both 'Georgia Jet' and 'Beauregard' were better adapted to higher latitudes compared with $\mathrm{OF}$ varieties such as Covington, Diane, Evangeline, Ginseng Red, Hernandez, and Porto Rico.

The objective of this study was to determine the performance and adaptability of eight commercial sweetpotato varieties and two unreleased accessions for production and direct marketing in Pennsylvania conditions under black plastic mulch in a mild temperate climate. The results of these evaluations over 2 years in Rock Springs, PA, are described.

\section{Methods}

This study was conducted over 2 years (2018 and 2019) at the Russell E. Larson Agricultural Research Center of The Pennsylvania State University located in Rock Springs, PA (lat. $40^{\circ} 42^{\prime} 38.1^{\prime \prime} \mathrm{N}$, long. $\left.77^{\circ} 57^{\prime} 52.07^{\prime \prime} \mathrm{W}\right)$. The field site is dominated by a Murrill channery silt loam soil (fine-loamy, mixed, semiactive, mesic Typic Hapludult), and slopes from $0 \%$ to $3 \%$. Monthly temperature and precipitation data were obtained from the Network for Environmental and Weather Applications, Rock Springs, PA, weather station (lat. $40^{\circ} 42^{\prime} 32.5^{\prime \prime} \mathrm{N}$, long. $77^{\circ} 57^{\prime} 06.9^{\prime \prime} \mathrm{W}$ ).

All sweetpotato slips used for both years were G2 planting stock provided by K.V. Pecota of North Carolina State University, Raleigh (Table 1). For the 2018 field trial, 'Japanese' and NCP13-0030 were not evaluated. For the 2019 field trial, 'Murasaki' and NC4l3 were not evaluated.

A combination raised bedmulch-drip tape layer (model 2400 Mini Layer; Rain-Flo Irrigation, East Earl, PA) was used to form raised beds 36 inches wide and 8 inches high. Each bed was covered with 1-milthick black embossed plastic mulch (part no. BLK324, Rain-Flo Irrigation). Distance between bed centers was $5 \mathrm{ft}$. A single line of 6-mil-thick drip irrigation tape with 8 -inch emitter spacing (T-Tape; $\mathrm{T}$ Systems International, San Diego, CA) was laid under the plastic mulch for each row. Slips were spaced 12 inches apart in a single row and hand-planted into plastic mulch on 28 May 2018 and 31 May 2019. All trials used a randomized complete block design with four replicates of 10 plants per experimental plot, with a 5 - $\mathrm{ft}$ break between plots.

The preceding crops were rye (Secale cereale) and white clover (Trifolium repens), both used as cover crops in 2018, and tomato (Solanum lycopersicum) in 2019. The field soil was a Murrill channery silt loam. Soil tests were done $15 \mathrm{~d}$ before field preparation for both years and were performed by the Agricultural Analytical Services Laboratory of The Pennsylvania State University, University Park. Soil tests showed phosphorus $(\mathrm{P})$ levels at $213.8 \mathrm{lb} /$ acre and potassium $(\mathrm{K})$ levels at $198.4 \mathrm{lb} /$ acre as determined by the Mehlich 3 soil test. Before laying down the black plastic mulch, $35 \mathrm{lb} /$ acre of calcium nitrate $(15.5 \mathrm{~N}-0 \mathrm{P}-0 \mathrm{~K})$ and $55 \mathrm{lb} /$ acre of magnesium sulfate $(0 \mathrm{~N}-0 \mathrm{P}-$ $0 \mathrm{~K}-9 \mathrm{Mg}$ ) were incorporated preplanting based on soil test reports. After $30 \mathrm{~d}$ (storage root initiation period), an additional $35 \mathrm{lb} /$ acre calcium nitrate was fertigated. The fertilization regime remained the same for both years. All trials were drip irrigated as needed using the "feel and appearance" method (USDA, Natural Resources

Table 1. Origin, skin, and flesh colors of commercial sweetpotato varieties and unreleased accessions evaluated in Rock Springs, PA, in 2018 and 2019.

\begin{tabular}{|c|c|c|c|c|}
\hline Variety or accession & Source & Skin color & Flesh color & $\operatorname{Yr}(\mathrm{s})$ used \\
\hline Averre & North Carolina State University, Raleigh & Orange/copper & Orange & 2018,2019 \\
\hline Beauregard & $\begin{array}{l}\text { Louisiana State University, Baton Rouge } \\
\text { (Rolston et al., 1987) }\end{array}$ & Orange/copper & Orange & 2018,2019 \\
\hline Bonita & $\begin{array}{l}\text { Louisiana State University, Baton Rouge } \\
\quad \text { (La Bonte et al., 2011) }\end{array}$ & Tan & White & 2018,2019 \\
\hline Carolina Ruby & $\begin{array}{l}\text { North Carolina State University, Raleigh } \\
\text { (Collins et al., 1999) }\end{array}$ & Red & Orange & 2018,2019 \\
\hline Covington & $\begin{array}{l}\text { North Carolina State University, Raleigh } \\
\quad \text { (Yencho et al., 2008) }\end{array}$ & Orange/copper & Orange & 2018,2019 \\
\hline Japanese & Unknown & Purple & White & 2019 \\
\hline Murasaki & $\begin{array}{l}\text { Louisiana State University, Baton Rouge } \\
\text { (La Bonte et al., 2008) }\end{array}$ & Purple & White & 2018 \\
\hline $\mathrm{NC} 413^{\mathrm{z}}$ & North Carolina State University, Raleigh & Purple & Purple & 2018 \\
\hline Orleans & $\begin{array}{l}\text { Louisiana State University, Baton Rouge } \\
\text { (La Bonte et al., 2011) }\end{array}$ & Light rose & Orange & 2018,2019 \\
\hline NCP13-0030 & North Carolina State University, Raleigh & Purple & Purple & 2019 \\
\hline
\end{tabular}

${ }^{\mathrm{z}}$ Unreleased accession. 
Conservation Service, 1998) throughout the growing season. Manual weeding between rows was done periodically in June and July of each year. By August, sweetpotato vines grew and spread enough to prevent any weed growth between the rows.

Sweetpotatoes were harvested on 2 and 3 Oct. 2018, which corresponded to 127 and $128 \mathrm{~d}$ after transplanting, and on 30 Sept. and 1 Oct. 2019 , which corresponded to 123 and $124 \mathrm{~d}$ after transplanting. Vines were detached using a walk-behind string trimmer (model ST 100; Cub Cadet, Cleveland, $\mathrm{OH}$ ), and plastic mulch was removed by hand. Storage roots were lifted using a one-row potato digger (model D-10M; U.S. Small Farm Equipment Co., Worland, WY) and were sorted into the following categories using U.S. standards for grades of sweetpotatoes (USDA, Agricultural Marketing Service, 2005): U.S. No.1 [maximum (max.) diameter, 3.5 inches; minimum (min.) diameter, 1.75 inches; max. length, 9 inches; min. length, 3 inches], jumbo (diameter, >3.5 inches; length, $>9$ inches), canner (max. diameter, 2.25 inches; min. diameter, 1.5 inches; max. length, 7 inches; min. length, 3 inches), and cull (storage roots of any size that exhibited off-shapes and/or damages from bruises, scarring, growth cracks, decay, insects, or other means). TMY equals the sum of all categories excluding cull. TY equals TMY plus cull.
All roots were counted, sized, and weighed. Data were tested for normality and subjected to analysis of variance using JMP Pro (version 14; SAS Institute, Cary, NC). When comparing varieties and accessions, when the overall $\mathrm{F}$ test was significant $(P \leq$ $0.05)$, means separations were evaluated using Tukey's honestly significant difference test at $P \leq 0.05$.

\section{Results}

Daily maximum, minimum, and mean air temperatures, and precipitation data are shown for the 2018 and 2019 growing seasons for Rock Springs, PA (Fig. 1). These data are presented to show the stark deviations from the norm during the trial period in 2018 compared with 2019, and to provide an assessment of fluctuating weather patterns for Pennsylvania. Overall, 2018 was warmer and wetter compared with 2019. Pennsylvania registered the wettest July (2018) in recorded history, with a mean precipitation of 7.53 inches and a 6-month mean of 6.29 inches (MayOctober). In 2018, mean air temperature averaged $64.7^{\circ} \mathrm{F}$ (6-month mean, May-October) compared with $65.5^{\circ} \mathrm{F}$ in 2019 (Northeast Regional Climate Center, 2020). The 2019 growing season presented slightly cooler and drier weather typical of Pennsylvania.

For 2018, TMY of the highest yielding sweetpotato varieties were Averre, Covington, Orleans, and Beauregard (range, 548-706 bushels/acre;
$50 \mathrm{lb} /$ bushel), whereas the lowest yielding accession (NC413) produced as little as 82 bushels/acre. In contrast, TMY ranged from 432 to 320 bushels/acre for 2019. In both years, 'Orleans', 'Covington', 'Beauregard', and 'Averre' either produced the highest yields of marketable roots or produced yields not significantly different from each other (Table 2). Both 'Murasaki' and NC413 produced the lowest TMYs in 2018, with 323 and 82 bushels/acre, respectively. Because of the low production, this variety and accession were omitted and replaced with 'Japanese' and NCP13-0030 for the 2019 growing season. 'Beauregard' produced the highest yield of jumbo, with $12 \mathrm{lb} /$ plot (10 plants/plot), whereas 'Bonita' produced the least amount $(0.3 \mathrm{lb} / \mathrm{plot})$ for 2018 . Jumbo yield for 2019 was between 0.4 and 2.8 $\mathrm{lb} /$ plot. Both 'Averre' and 'Covington' consistently produced the highest yield of canner in both years (mean, 3.3 and $5.1 \mathrm{lb} /$ plot, respectively). The cull category was dominated by both ' $\mathrm{Cov}$ ington' and 'Beauregard', which consistently exhibited signs of growth cracks and off-shapes, and resulted in cull yields between 7.3 and $8.7 \mathrm{lb} /$ plot, respectively, for 2018. Interestingly for 2019 , all varieties and accessions examined presented very low cull yields (range, $0.1-2.4 \mathrm{lb} / \mathrm{plot}$ ). For the U.S. No.1 category, all varieties and accessions tested during both years were examined rigorously (free from any physical damage), measured, and
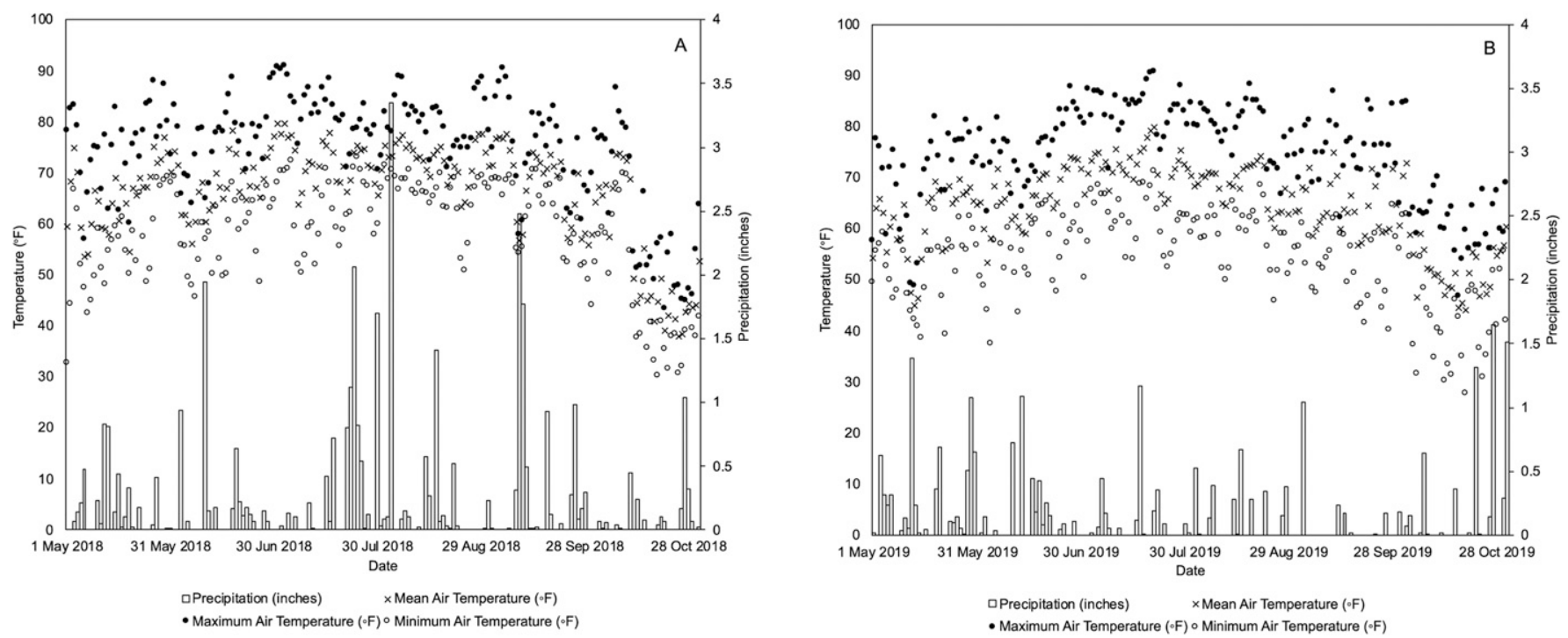

Fig. 1. Daily precipitation and air temperature at Rock Springs, PA, field sites during the (A) 2018 and (B) 2019 growing seasons. $\left({ }^{\circ} \mathrm{C} \times 1.8\right)+32={ }^{\circ} \mathrm{F}, 1$ inch $=2.54 \mathrm{~cm}$. 


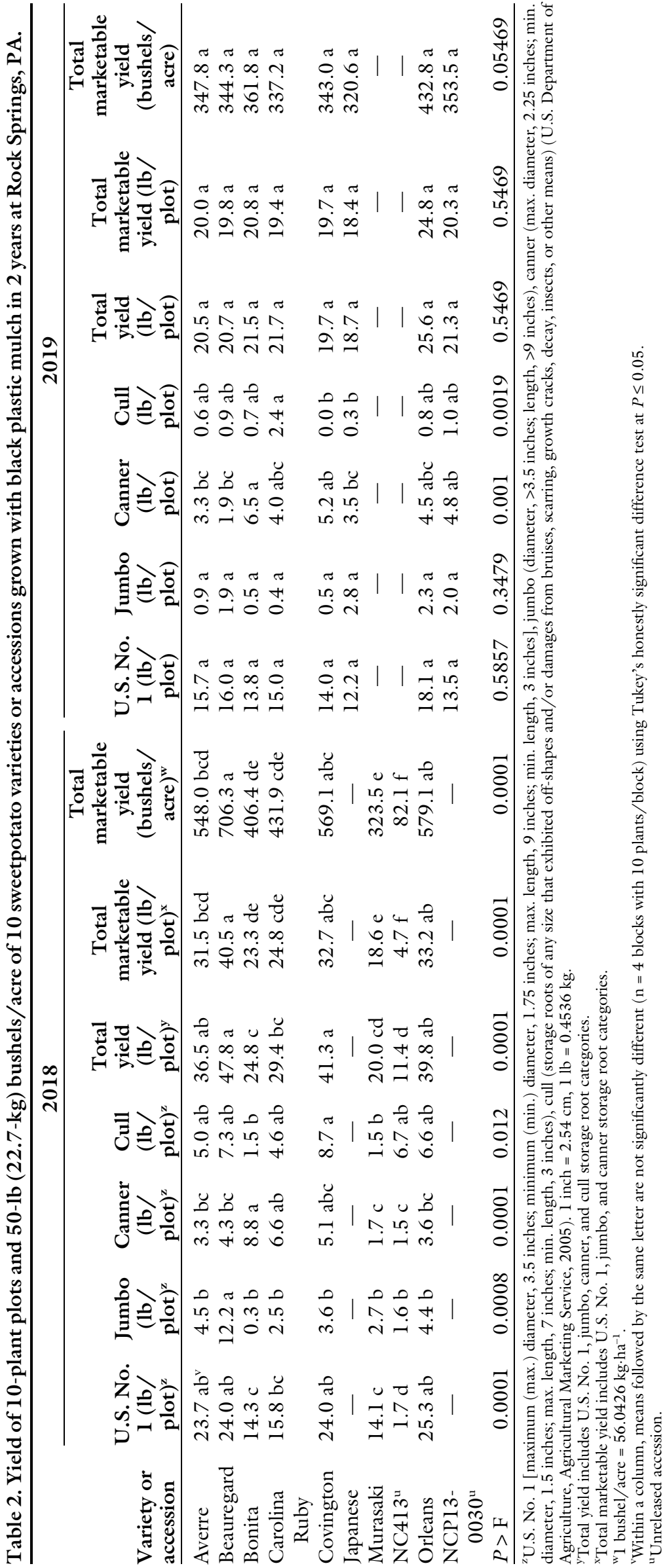

weighed to account for differences between jumbo and canner. For both years, 'Orleans', 'Beauregard', 'Averre', and 'Covington' consistently produced the highest yield of U.S. No. I when compared with other varieties and accessions. However, when comparing both years separately, there was a $17.3 \%$ yield reduction in 2019 (311 to 257 bushels/acre).

'Averre', an orange skin (OS)/ OF new entry from North Carolina State University, produces storage roots that are longer than 'Covington' but straighter than 'Beauregard', with TMYs similar to 'Covington' and 'Beauregard'. The results of this study show that 'Averre' performed well, and U.S. No. 1 yields were similar to 'Covington' and 'Beauregard' in both years (Table 2). 'Carolina Ruby', 'Bonita', and 'Murasaki' had acceptable U.S. No. 1 yields but overall lower TMYs when compared with OS/OF varieties. 'Murasaki' and 'Japanese', both PS/white flesh (WF) were used only once in different years; however, U.S. No. 1 yield for both varieties ranged between 12 and $14 \mathrm{lb} /$ plot, similar to 'Bonita' and 'Carolina Ruby' across both years. Two novel PS/PF unreleased accessions from North Carolina State University were analyzed in different years (NC413 in 2018 and NCPl30030 in 2019). First, NC413 yielded poorly, with a TMY of 82 bushels/ acre. This accession tended to grow very long, slender roots, probably a result of the soil texture present in the 2018 field site (silt loam). However, NCP13-0030, presented a TMY of $>400$ bushels/acre, with a U.S. No. 1 yield of $18 \mathrm{lb} /$ plot in 2019 . This accession displayed excellent shapes, and deep PF color attributes and with no signs of physical damage.

\section{Discussion}

The results of this study show that sweetpotato production is a possible and viable option for Pennsylvania vegetable growers in shorter growing seasons, under cooler temperatures, erratic and unpredictable rainfall patterns, and using varieties or accessions originally bred for warmer and longer growing periods. This is the first study that describes the performance of commercially available varieties and unreleased sweetpotato accessions in Pennsylvania. Regardless of the aforementioned challenges, 
the highest yielding varieties produced TMYs ranging from 548 to 706 bushels/acre. These values compare favorably to production ranges of the principal sweetpotato producing states, which are between 233 and 616 bushels/acre, with a national average of 316 bushels/acre for 2018 (USDA, NASS, 2020).

Many environmental factors have been studied to understand the effects of sweetpotato storage root formation. Lebot (2009) showed that greater light intensity and long days increase the number of sweetpotato storage roots, whereas formation and development of storage roots is promoted by shorter days. Pennsylvania is located both in the northern and western hemispheres, presenting longer days during the summer months with a peak of $\approx 15 \mathrm{~h}$ of daylight toward the end of June and a rapid decrease toward late summer and early fall $(\approx 12 \mathrm{~h}$ of daylight). This shift of daylight pattern might have contributed toward high yields despite a relatively short growing season. Sideman (2015) showed greater than normal sweetpotato yields compared with the national averages in New Hampshire, which has a slightly higher northern latitude compared with Pennsylvania. Another factor that could have promoted greater than normal sweetpotato yields was the use of black plastic mulch, although soil temperatures were not monitored during the trial periods. Plastic mulch films are used in the production of vegetables and other specialty crops globally because of the benefits they provide, such as weed, water, and temperature management. The use of plastic mulch can lead to better crop quality and yield, and to more efficient use of agricultural inputs (Hayes et al., 2019). Although the current study did not compare the use of plastic mulch vs. bare-soil planting, numerous studies using plastic mulch vs. bare soil with sweetpotato production have shown positive results. In a 2-year study using 'Beauregard' and biodegradable mulch, Sideman (2015) showed increased overall yields when compared with bare-soil production; however, with increased culls. Likewise, Wees et al. $(2015,2016)$ demonstrated high yields of 'Beauregard', 'Evangeline', and 'Georgia Jet' (18-25 th ha $\left.{ }^{-1}\right)$ under biodegradable mulch. Hochmuth and
Howell (1983) indicated yields of 'Jewel' to the magnitude of 32250 $\mathrm{lb}$ bushel/acre on raised beds covered with black plastic mulch in Massachusetts. Also, Brown et al. (1998) showed the positive effect of using black plastic mulch with row covers in sweetpotato yield compared with bare-soil production. Furthermore, many extension reports have shown the added benefit of using plastic mulch in sweetpotato production in Connecticut (Hill, 2001), Canada (Filotas, 2014), and New York (Bornt, 2012). The establishment stage of sweetpotato $(\approx 4$ weeks after planting $)$ is considered to be the most critical phase in the growing cycle because the development stage during this time largely determines later growth and later yield (Pardales and Esquibel, 1996). During this critical phase, drought stress can suppress both the development of adventitious as well as lateral roots, with potential storage root yield penalties. This drought stress can promote changes in the individual root components of a root system at any time, even though the crop had been exposed previously to well-watered conditions (Pardales and Yamauchi, 2003). During the 2018 growing season, Pennsylvania registered record precipitation, with means greater than 6 inches from early May to early September. Although soil water content was not measured for both years, there was no evidence of any drought stress in the study trials. Hence, overall greater yields for 2018 are possibly the result of extra soil moisture trapped under the plastic mulch and warmer air temperatures during the growing season compared with 2019.

Sweetpotatoes are typically grown for fresh-market consumption, but they are increasingly being used for value-added alternative markets such as processed foods (French fries and chips) and industrial products (starch, flour, food dyes), among others. In the United States, different color types of sweetpotatoes-for example, PF and cream flesh, as well as OF-are increasing in availability. In Pennsylvania, direct-market sales through local farmers' markets and grocery stores are the primary outlet for vegetable growers, and locally grown sweetpotatoes with proper postharvest handling can improve availability throughout the fall, winter, and spring seasons.
One main factor that has been well studied in the northeastern United States is the adaptability and adoptability of different sweetpotato varieties with diverse skin, flesh, and culinary attributes (Sideman, 2015; Wees et al., $2015,2016)$. In this study, eight different commercially available varieties and two unreleased accessions were examined for 2 years (Table 1 ). Interestingly, this is the first study that has evaluated two PS/PF accessions (NC413 and NCP13-0030) in the northeastern United States. Typically, consumer preference has been toward $\mathrm{OS} / \mathrm{OF}$ varieties (Covington, Beauregard, and Orleans) that have consistently greater yields and physical attributes; however, novel skin/flesh combinations such as 'Carolina Ruby' (red skin/OF), 'Bonita' (tan skin/tan flesh), and 'Murasaki' and 'Japanese' (PS/WF) presented acceptable yield and are of public interest. Overall, $\mathrm{OS} / \mathrm{OF}$ varieties outperformed all other accessions tested in both years (Table 2). The current study results are consistent with those of Sideman (2015), Wees et al. $(2015,2016)$, Nair et al. (2012), Goldy and Wendzel (2008), and Bornt (2012), where 'Beauregard' and 'Covington' consistently had greater yields and better physical attributes compared with other varieties tested.

Overall, these results suggest that 'Beauregard', 'Covington', 'Orleans', and 'Averre' (OS/OF) are recommended choices for Pennsylvania farmers as well as for the northeastern United States in regard to consistent yield and environmental adaptability. And with slightly lower TMYs, 'Carolina Ruby', 'Murasaki' / 'Japanese', 'Bonita', and NCPl30030 (unreleased accession) ensure a mix of colors, textures, and flavors that are desired for future emerging markets in Pennsylvania.

\section{Literature cited}

Bornt, C. 2012. Improving the yield and quality of sweet potatoes grown in New York, 2012 Final report. 6 July 2020. $<$ https://projects.sare.org/projectreports/lne10-292/>.

Bouwkamp, J.C. 1985. Sweet potato products. CRC Press, Boca Raton, FL.

Brown, J.E., F.M. Woods, and C. Channell-Butcher. 1998. Effect of black plastic mulch and row cover on sweet potato production. J. Veg. Crop. Prod. 4:49-54. 
Collins, W.W., K.V. Pecota, and G.C. Yencho. 1999. 'Carolina Ruby' sweetpotato. HortScience 34:155-156.

Filotas, M. 2014. Sweetpotato production in Ontario. 6 July 2020. <https:// onvegetables.files.wordpress.com/2014/ $05 /$ sweet-potato-meeting-leamingtonmarch-3-2014-postingl.pdf>

Goldy, R. and V. Wendzel. 2008. Evaluation of ten sweet potato cultivars in southwest Michigan. 6 July 2020. <https:// extension.umd.edu/sites/extension.umd. edu/files/_docs/programs/mdvegetables/ MidwestVegTrialReport_2008.pdfs.

Hayes, D.G., M.B. Anunciado, J.M. DeBruyn, S. Bandopadhyay, S. Schaeffer, M. English, S. Ghimire, C. Miles, M. Flury, and H.Y. Sintim. 2019. Biodegradable plastic mulch films for sustainable specialty crop production, $\mathrm{p}$. 183-213. In: T.J. Gutiérrez (ed.). Polymers for agri-food applications. Springer International Publishing, Cham, Switzerland.

Hill, D.E. 2001. Specialty crops: Okra, leek, sweet potato and jilo. Connecticut. Agr. Expt. Sta. Bul. 976.

Hochmuth, G.J. and J.C. Howell, Jr. 1983. Effect of black plastic mulch and raised beds on sweet potato growth and root yield in a northern region. HortScience 18:467-468.

Jansson, R.K. and K.V. Raman. 1991. Sweet potato pest management: A global overview, p. 1-12. In: R.K. Jansson and K.V. Raman (eds.). Sweet potato pest management: A global perspective. Westview Press, Boulder, CO.

La Bonte, D.R., A.Q. Villordon, C.A. Clark, P.W. Wilson, and C.S. Stoddard. 2008. 'Murasaki-29' sweetpotato. HortScience 43:1895.
La Bonte, D.R., C.A. Clark, T.P. Smith, and A.Q. Villordon. 2011. 'Bonita' sweetpotato. HortScience 46:948.

Lebot, V. 2009. Tropical root and tuber crops. CABI, Wallingford, UK.

Nair, A., B. Bergaum, and M. Bilenky. 2012. Sweet potato cultivar trial. 6 July 2020. <https://www.iastatedigitalpress. com/farmreports/article/4530/galley/ 4396/view/>.

Northeast Regional Climate Center. 2020. Northeast Regional Climate Center. 10 July 2020. <http://www.nrcc. cornell.edu $/>$.

Pardales, J.R., Jr. and C.B. Esquibel. 1996. Effect of drought during the establishment period on the root system development of cassava. Jpn. J. Crop. Sci. 65:93-97.

Pardales, J.R., Jr. and A. Yamauchi. 2003. Regulation of root development in sweetpotato and cassava by soil moisture during their establishment period, p. 201-208. In: J. Abe (ed.). Roots: The dynamic interface between plants and the earth. Springer, New York, NY.

Rolston, L.H., C.A. Clark, J.M. Cannon, W.M. Randle, E.G. Riley, P.W. Wilson, and M.L. Robbins. 1987. 'Beauregard' sweet potato. HortScience 22:13381339.

Sideman, R.G. 2015. Performance of sweetpotato cultivars grown using biodegradable black plastic mulch in New Hampshire. HortTechnology 25:412416.

U.S. Department of Agriculture, Agricultural Marketing Service. 2005. United States standards for grade of sweetpotatoes. 6 July 2020. <https://www. ams.usda.gov/sites/default/files/
media/Sweetpotato_Standard\%5B1\%5D. pdf>.

U.S. Department of Agriculture, National Agricultural Statistics Service (USDA, NASS). 2019. 2017 Census of agriculture. 6 July 2020. <https://www.nass. usda.gov/Publications/AgCensus / $2017 /$ Full_Report/Volume_1,_ Chapter_1_US/usvl.pdf $>$.

U.S. Department of Agriculture, National Agricultural Statistics Services (USDA, NASS). 2020. Acreage. 6 July 2020. <https://downloads.usda.library.cornell. edu/usda-esmis /files /j098zb09z/ gb 19f7847/ng451k9lv/Acre-06-292018.pdf>.

U.S. Department of Agriculture, Natural Resources Conservation Service. 1998. Estimating soil moisture by feel and appearance. 6 Aug. 2020. <https://www.nrcs.usda. gov/Internet/FSE_DOCUMENTS/ nrcs144p2_051845.pdf>.

Wees, D., P. Seguin, and J. Boisclair. 2016. Sweet potato production in a shortseason area utilizing black plastic mulch: Effects of cultivar, in-row plant spacing, and harvest date on yield parameters. Can. J. Plant Sci. 96:139-147.

Wees, D., P. Seguin, J. Boisclair, and C. Gendre. 2015. Performance and quality of sweetpotato cultivars grown in Quebec, Canada with biodegradable plastic mulch. HortTechnology 25:815.

Yencho, G.C., K.V. Pecota, J.R. Schultheis, Z.P. VanEsbroeck, G.J. Holmes, B.E. Little, A.C. Thornton, and V.D. Truong. 2008. 'Covington' sweetpotato. HortScience 43:1911-1914. 